\title{
Den Gud gir et embete, gir han også forstand
}

\author{
Mange kjenner dette ordtaket - men hvor kommer det fra, hva betyr det og hvorfor omtale det i Språkspalten?
}

I det vanligvis så etterrettelige verket Bevingede ord står det at opphavsmannen var tyskeren Theophilius Wilhelm Rabener (171471). På tysk går det slik: «Wem Gott ein Amt gibt, dem gibt er auch Verstand» (1). Men i leksikonet nevnes ikke Rabener. Der står det kun at dette er et gammelt tysk ordspråk (2). Hvordan har det seg? Ordtaket er populært og omtalt i Tidsskriftet flere ganger (3-5).

Theophilius Wilhelm Rabener var forfatter og satiriker. Fornavnet skrives på tysk Gottlieb, Theophilius er latinsk navneform. Han var utdannet jurist og endte opp som overskattesekretær i Dresden (6). I dag er han glemt (7), men i sin samtid ble han omtalt som Tysklands Jonathan Swift (1667-1745) (8). Han samlet stoff til satirer på sine embetsreiser og utga dem i fire bind $i$ årene 175155. I siste bind skrev han kommentarer til ordspråk (6). Det er her han har et kapittel om «Wem Gott ein Amt...» (9). Det er altså ikke Rabener som er opphavsmannen. Det hevder han ikke selv heller.

Opphavet er nok mye eldre. Det har vært fremholdt at det stammer fra 1500-tallet (10). Det er i hvert fall sannsynlig at det er middelaldersk. Men det er som med de fleste ordspråk, deres opprinnelse og alder er ofte ikke lett å fastslå (11). De gir gjerne uttrykk for en allmenn, menneskelig erfaring, og samme tanke kan finnes igjen i ordspråk fra flere kulturer (11). Som eventyrene har de også ofte vandret fra land til land. Noen ordspråk kan imidlertid føres tilbake til en bestemt kilde, Bibelen ikke minst (11). Det kan hende at det også gjelder «Den Gud gir...» (12). Uttrykket har vært satt i forbindelse med bibelordet: «I Herrens hånd er en manns lykke, og en embedsmann gir han den ære ham tilkommer» $(1,13)$.

\section{Mange varianter}

Ordspråket finnes i en rekke versjoner (1). Som mange andre gode ordtak har også dette utviklet seg i flere retninger (14). Den danske forfatteren Erik Bøgh (1822-99) skrev på midten av 1800-tallet: «Hvem Gud gi'er et Embede, gi'er han Forstand - den Sætning er stundom bestredet; men giver han ikke Forstanden - saa kan en Fuldmægtig bruges i Stedet» $(1,15)$. Den tyske romantiske forfatteren Jean Paul (1763-1825) er tillagt formen: «Den Gud gir et embete, ham gir han også, om ikke forstand, så iallfall en kone» (16). Vår egen Alexander Kielland (18491906) bruker det slik: «den hvem Gud gir et

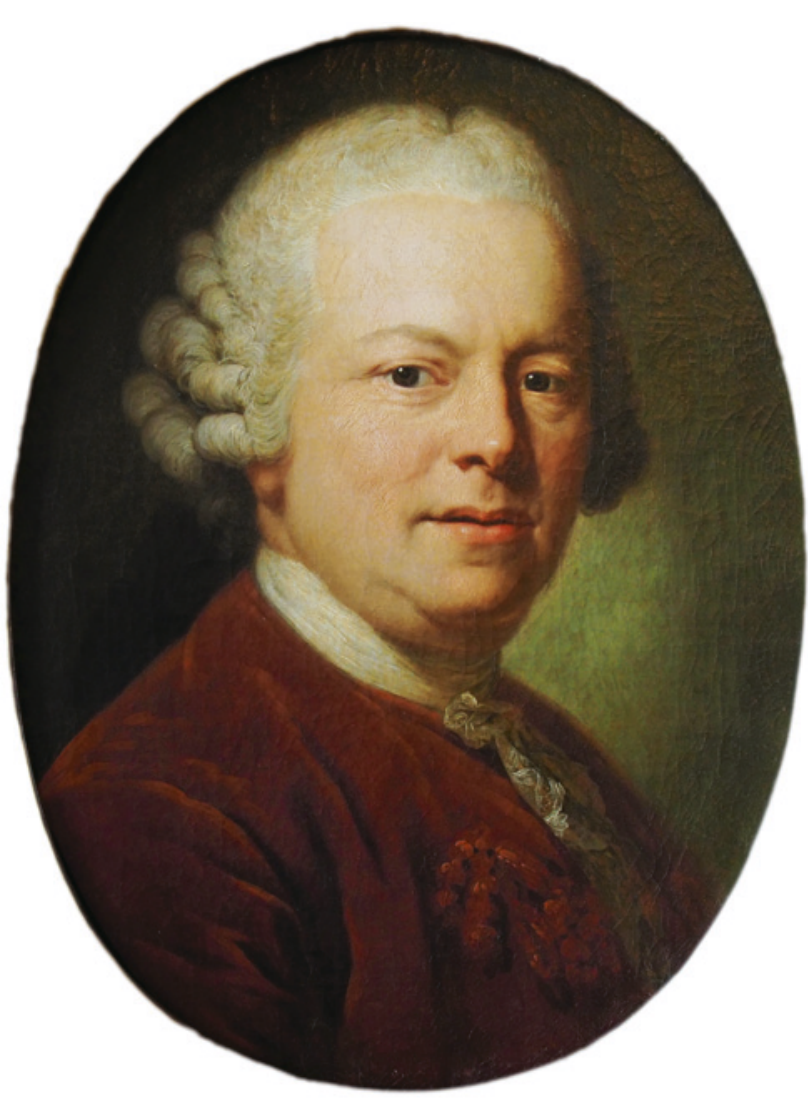

Gottlieb Wilhelm Rabener malt av Anton Graff. Wikimedia Commons

embede, ham vil han også skjenke evne og kraft til å forvalte det» (17). Hos Ivar Aasen (1813-96) heter det: «Den som vår Herre giv Embætte, giv han Vit med» $(18,19)$.

Fra nyere tid har vi historien om Venstres parlamentariske leder Bent Røiseland (190281) som lanserte en ny tilføyelse i Stortinget under regjeringskrisen høsten 1963: «men det gjeld vel ikkje berre for Arbeiderpartiet sine statsråder!» (2). «Hadde det enda vært så vel at den gud gav forstand, gav han også embete», er en annen variant som også skal stamme fra 1960-årene (20).

\section{Konjunktiv?}

Det er en utbredt oppfatning at dette uttrykket opprinnelig hadde konjunktivisk form og dermed ga uttrykk for et ønske (21).

Betydningen ville da være omtrent: La oss håpe at når $\mathrm{Gud}$ gir noen et embete, da gir han denne personen også forstand. Slik har man forsøkt å justere det til: «...ham give han også forstand». Men i den opprin- nelige versjonen finnes det ingen konjunktiv (21).

Det er ikke så rart at noen tror det må være en konjunktiv her. Det lyder jo merkelig at et menneske som gis et embete, automatisk også skulle gis forstand. Men meningen er naturligvis satirisk og henspiller kanskje på middelalderens syn på styresett av «Guds nåde». «Der Satz ist also ironisch gemeint»», som det står i en tysk kilde (10). Hegel (1770-1831) kaller det en gammel spøk (22).

I norsk er konjunktiv (også kalt ønskemåte eller optativ) trengt sterkt tilbake og finnes nå bare i enkelte rester (23). Hos oss forekommer den først og fremst i ønsker, f.eks. «Herren velsigne deg og bevare deg», «Leve kongen», «Skam få den som ikke, Einar sin skål vil drikke», osv. $(23,24)$. Et eksempel finner vi i medisinen også. Når vi på reseptene skriver «Reit» (forkortelse av reiteretur), er det en passiv konjunktiv av reiterare, som betyr «gjenta, fornye» (25). 


\section{Kort sagt}

«Den Gud gir et embete, gir han også forstand» er et gammelt tysk ordtak, sannsynligvis fra middelalderen. Det finnes i en rekke varianter. Mange tror at ordtaket egentlig skal være formulert med en konjunktiv, altså at man gir uttrykk for et ønske. Men slik er det ikke.

Jeg takker Peter Schröder for nyttige opplysnin ger.

\section{Erlend Hem}

erlend.hem@medisin.uio.no

Tidsskriftet

Erlend Hem (f. 1970) er dr.med., fagsjef i Klinikk psykisk helse og avhengighet, Oslo universitetssykehus, og redaktør for Tidsskriftets språkspalte.

\section{Litteratur}

1. Gundersen D, Evensberget S. Bevingede ord. 4. utg Oslo: Kunnskapsforlaget, 2006: 123.

2. Den Gud gir et embete, gir Han også forstand. (14.2.2009). I: Store norske leksikon.

https://snl.no/Den_Gud_gir_et_embete\%2C_gir han ogs $\%$ C3\%A5 forstand $(22.11 .2015$.
3. Skatteboe E. Fleip eller fakta. Tidsskr Nor Legeforen 2012: 132: 2599

4. Kjellevand TO. Om embete og forstand. Tidsskr Nor Legeforen 2013; 133: 384.

5. Ertresvåg K. Den Gud gir et embete. Tidsskr Nor Legeforen 2013; 133: 830.

6. Jansen FJB. Verdens litteraturhistorie. Bd. 5: Opplysningstiden (1700-1750): Oslo: Cappelen, 1972: 342-5. www.nb.no/nbsok/nb/dd5966014b2c67eeb 9353b5644246fc0?index=1\#351 (22.11.2015)

7. Gottlieb Wilhelm Rabener. Tysk Wikipedia. https://de.wikipedia.org/wiki/ Gottlieb Wilhelm Rabener (22.11.2015)

8. Gottlieb Wilhelm Rabener. I: Blangstrup C, red. Salmonsens konversationsleksikon. 2. utg. Bd 19 Perlit-Rendehest. København: Schultz, 1924: 814 http://runeberg.org/salmonsen/2/19/0840.html (22.11.2015).

9. Rabener GW. Sammlung satirischer Schriften Bd. 4. Leipzig, 1755. www.deutschestextarchiv.de/ book/view/rabener sammlung04 1755? p =49 (22.11.2015).

10. Wem Gott ein Amt gibt, dem gibt er auch Verstand. Liste geflügelter Worte/W. https://de.wikipedia.org/ wiki/Liste gefl\%C3\%BCgelter Worte/W (22.11.2015).

11. Ordspråk. (14.2.2009). I: Store norske leksikon. https://snl.no/ordspr\%C3\%A5k (22.11.2015).

12. Gottlieb Wilhelm Rabener. Svensk Wikipedia. https://sv.wikipedia.org/wiki/ Gottlieb Wilhelm Rabener (22.11.2015).

13. Sirak 10,5. Bibelen. www.bibel.no/ Nettbibelen. aspx?book $=$ SIR \& chapter $=10 \&$ verse $=5$ (22.11.2015).

14. Lærum OD, Stien R, Hem E. «Jeg er norsk læge»et sitat med eget liv. Tidsskr Nor Legeforen 2013; 133: $2490-2$

15. Embede. I: Ordbog over det danske Sprog. http://ordnet.dk/ods/ordbog?query=embede $\&$ tab= for (22.11.2015)

16. Gyllstoff H. red. Norsk sitatleksikon: 6000 bevingede ord. Stavanger: Stabenfeldt, 1949: 87 www.nb.no/nbsok/nb/d81cd400035328bd89f9868b 6162272f?index=90\#61 (22.11.2015).

17. Kielland AL. Arbeidsfolk. I: Samlede verker. Bd. 2 15. utg. Oslo: Gyldendal, 1999: 109. www.nb.no/ $\mathrm{nbsok} / \mathrm{nb} / \mathrm{fd} 29 \mathrm{e} 959 \mathrm{c} 3 \mathrm{~d} 51632829923 \mathrm{f3a09ff0d1}$ ? index=8\#110 (22.11.2015)

18. Aasen I. Norske ordsprog. 3. utg. Voss: Vestanbok forlag. 1982: 47. www nb no/nbsok/nb/18cbe83c25 e7ab91a1 fbbecab23e4193.nbdigital?lang=no \#48 (22.11.2015).

19. Sprichwörter der germanischen und romanischen Sprachen vergleichend zusammengestellt von Ida von Düringsfeld und Otto Freiherrn von ReinsbergDüringsfeld. Bd. 1. Leipzig: Hermann Fries, 1872: 38. https://archive.org/stream/ sprichwrterder01druoft\#page/38 (22.11.2015)

20. Embede. I: Norsk riksmålsordbok. www.ordnett.no/ search? search=embede\&lang=no $(22.11 .2015)$

21. Vinje F-E. Riktig norsk. 4. utg. Oslo : Vidarforlaget, 2014: 202.

22. De store tænkere: Hegel. 2. utg. Oslo: Tano, 1991 99 www nb no/nbsok/nb/2510eb2af48c84976dfca $5 f 94117607 \mathrm{e}$ ? index=13\#100 (22.11.2015).

23. Vinje F-E. Konjunktiv på retur. Finn-Erik Vinjes blogg 15.11.2011. www.finnerikvinje.no/blog/ $? p=12448$ (22.11.2015)

24. Vinje F-E. Norsk grammatikk: det språklige byggverket. Oslo: Kunnskapsforlaget, 2005: 138

25. Vinje F-E. Latinen hjelper meget. Finn-Erik Vinjes blogg 19.11.2008. www. finnerikvinje.no/blog/ $? p=415(22.11 .2015)$ 